\title{
A Comparison Of Private And Public Sector Performance
}

\author{
Barbara Caemmerer, ESSCA School of Management, LUNAM University, France
}

Alistair Dewar, Lloyds Banking Group, United Kingdom

\begin{abstract}
In the past, public sector organizations have been used as examples of service atrocities - but in light of unstable overall customer satisfaction levels across countries and industries the purpose of this research note is to investigate whether their private counterparts fare much better in terms of service performance. A quantitative, quasi-experimental study was carried out with 200 respondents. The survey tool was based on the SERVQUAL framework to compare recipients' service expectations and perceptions in private and public service settings. The results reveal no significant differences between expectations towards and perceptions of private and public services. The traditional SERVQUAL dimensions explain $74 \%$ of overall satisfaction in the public, and $87 \%$ in the private sector. As this is a cross-sectional study more research is necessary to understand whether the results are due to an amelioration in the public and a deterioration in the private sector, or vice versa, or neither. The study stimulates debate and further research into the underlying reasons for customers' similar expectations and perceptions across sectors. Is actual service performance across sectors assimilating? Or do perceptions in one sector setting impact on expectations and perceptions in another?
\end{abstract}

Keywords: Cross-Sectoral Comparison; Service Quality; Service Satisfaction; SERVQUAL

\section{INTRODUCTION}

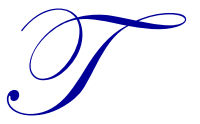

he service quality concept has been widely debated in the marketing literature (e.g. Bowman and Narayandas, 2004; Chiao and Droge, 2006; Durvasula et al., 2005; Koutroumanis et al., 2012; Parasuraman et al., 1985, 1988; Piercy and Rich, 2008). The main rationale comes from private sector research which suggests that higher levels of service quality may be positively linked to organizational longterm profitability (Zeithaml et al., 2006). Well established concepts, such as the service-profit chain, support the notion that internal operational input into the service delivery process impact on external customers' perceptions of service quality, their overall satisfaction with the services received, and their intention to engage in repeat business with the organization (Heskett et al., 1994). As such, service quality has been treated as a key antecedent of customer satisfaction and organizational success in the private sector over the last two decades (Gronroos, 1982; Jamal and Anastasiadou, 2009).

In parallel, the concept has also gained increased attention in the public administration literature: Over the last three decades, governmental cost-cutting on the one hand and growing public pressure on the other have given impetus to the modernisation and improvement of public services (Black et al., 2001; Bolton, 2003; Coplin et al., 2002; Donnelly et al., 1995; Maddock, 2002; McAdam et al., 2002; Micheli et al., 2005; Rhee and Rha, 2009). Therefore, the improvement of service quality has also become a critical issue for the public sector (Radnor and McGuire, 2004; Woodell, 2002). As it has been suggested that the underlying delivery processes in public services are similar to the private sector, private sector practices have often been used as a model for improving the quality of public sector services (Galloway, 1998). While it has been observed that an assimilation between private and public sector service management practices takes place (Caemmerer and Banerjee, 2009), little is known about how the levels of service quality compare between private and public services. The purpose of this research is thus to look at the service management assimilation phenomenon from a recipient perspective and compare service expectations and perceptions in the private and the public sector. 


\section{SERVICE QUALITY - CONCEPT AND MEASUREMENT}

In the services marketing literature the term service quality is used to describe service performance (Buttle, 1996; Gronroos, 1982; Voss et al., 2004; Zeithaml et al., 1996). This is reflected in the broad conceptualisation of the term proposed by Hoffman and Bateson (1997), who suggest that service quality is an evaluation, and therefore a cognitive process, which results in the formation of an attitude. Moreover, there seems to be some agreement that customers' perceptions of service quality may largely depend on the interaction with customer facing employees during the service delivery process (Gronroos, 1990; Zeithaml and Bitner, 2000). As the notion prevails that service quality may be linked to customer satisfaction, which in turn may impact positively on an organization's long-term success, many authors have focused on the development and discussion of measurement tools that capture customer feedback in relation to service quality (Caruana, 2002; Rosen and Surprenant, 1998; Turner et al., 2010). For example, SERVQUAL (Parasuraman et al., 1985, 1988) measures the gap scores between customers' expectations and subsequent perceptions of a service. While SERVQUAL is the most prominent service quality measurement tool in the literature, it has also been argued that direct measures of service performance, such as SERVPERF (Cronin and Taylor, 1992), may reflect levels of service quality more accurately than tools that are based on the expectancy-disconfirmation model (Rosen and Surprenant, 1998). Regardless of the measurement approach, it is worthwhile noting that although the service quality concept has been exhaustively debated in the academic and practitioner literature, market research shows that overall customer satisfaction levels across countries and industries customer satisfaction is unstable (e.g. EPSI, 1999-2009) and that customer complaints are on the rise (e.g. ICS, 2009).

\section{THE RISE OF SERVICE QUALITY IN THE PUBLIC SECTOR}

While the concept of service quality has, in general, attracted great attention in the private sector for a long time, it has only entered the debate in the public administration literature more recently. Traditionally, public sector organizations have been influenced and defined by political authorities and central bureaucratic agencies (Kondylis, 1989; Parker and Bradley, 2000). In this bureaucratic model public sector employees followed burdensome procedures by principle to demonstrate accountability to the public (Claver et al., 1999; Bolton, 2003). The provision of services was thus more internally focused than being focused towards the needs of the citizen. As such, the concept of service quality from the recipients' perspective was irrelevant.

With the introduction of the New Public Management approach it was hoped to develop a new service orientation amongst public sector organizations. This market-driven (Gianakis, 2002), organizational change agenda is "oriented towards the development of post-bureaucratic organizational forms" (Parker and Bradley, 2000, p 125) and the delivery of effective and efficient services as well as their improvement. However, critics argue that many public sector organizations struggle with this re-orientation due to the complexities of the environment they are operating in. For example, Marini (1993) highlights that public sector organizations are often used to illustrate examples of service atrocities. Important to note in this entire debate is the dominating managerial focus, centring around questions concerning management, change to organizational structures and processes, and the problems and issues that managers and employees face in this transition. Less attention is paid to the impact a potential service performance assimilation between sectors has on recipients.

\section{HOW DOES SERVICE PERFORMANCE COMPARE BETWEEN SECTORS?}

From the recipients' perspective, it is possible that service expectations between public and private sectors converge. The experience of private sector services of one customers may influence the same person's expectations and experience of public services as a citizen, and vice versa (du Gay and Salaman, 1992). On the other hand, recipients' perceptions of service quality between sectors may vary, depending on the service performance they encounter. While there is growing evidence that private and public sector management practices have assimilated, little research has been carried out to actually compare levels of service performance and satisfaction between the two sectors from a recipient's viewpoint. On the basis of the above discussion the following research objectives will be addressed with this study:

1) Compare recipients' expectations and perceptions of service quality between the private and public sector 
2) Compare overall satisfaction with the services received from the private and the public sector

3) Compare the antecedents of overall service satisfaction in the private and the public sector

\section{RESEARCH METHOD}

While SERVQUAL has been criticised by some authors for containing dimensions which are irrelevant or not applicable to all service settings, there is also a body of research which supports the notion that the tool contains good statistical properties and can be applied across service contexts (Arambewela and Hall, 2006; Brysland and Currie, 2001). However, as there is controversy around the reliability of gap scores, the research instrument used for this study only assessed service perceptions on the SERVQUAL dimensions (Cronin and Taylor, 1992). 22-items, measured on a 7-point Likert scale, were used to assess perceptions in relation to tangibles, reliability, responsiveness, assurance, and empathy. In addition, two questions were included assessing recipients' general service quality expectations before the service, as well as their overall satisfaction after the service.

Using a quasi-experimental approach, two versions of the questionnaire were created. In one, respondents were asked to fill in the questionnaire with respect to a public service they had recently received, and the other with respect to a private service. Copies of each version were distributed to respondents using quota sampling, resulting in 200 responses in total (100 for each version). It was ensured that there was a similar distribution across groups in terms of age $\left(\chi^{2}(1)=27.79\right.$, n.s. $)$ and gender $\left(\chi^{2}(1)=2.53\right.$, n.s. $)$.

\section{KEY FINDINGS}

Preliminary analysis revealed that the internal consistency of all five SERVQUAL dimensions was good in both, the public and the private sector group (Cronbach's alpha >.7) (Murphy and Davidshofer, 1998). Using AMOS, confirmatory factor analyses were carried out for the public and the private sector group independently, including the five latent SERVQUAL constructs and the measurement variables used to assess them. The chi-square value of the models is significant in the public sector $\left(\chi^{2}[199]=378.94, \mathrm{CMIN} / \mathrm{DF}=1.904, \mathrm{p}<.01\right)$, as well as in the private sector group $\left(\chi^{2}[199]=448.22, \mathrm{CMIN} / \mathrm{DF}=2.252, \mathrm{p}<.01\right)$. The model fit indexes suggest that the model fits the data of both groups adequately (public sector: $\mathrm{CFI}=0.91, \mathrm{RMSEA}=0.9$; private sector: $\mathrm{CFI}=0.90, \mathrm{RMSEA}=0.10$ ) (Byrne, 2001).

In order to address research objective 1 and 2, independent samples t-tests were carried out to compare overall expectations towards and perceptions of services between the two sectors, as well as overall levels of satisfaction with the services received. The results of this analysis are summarised in Table 1. As can be seen, overall service expectations and service satisfaction are slightly lower in the public sector. However, these results are not significant. Perceptions of services are significantly lower in the public sector on the tangibles dimension and less favourable on the responsiveness dimension. On the other hand, the public sector scores marginally better on the remaining three dimensions reliability, assurance and empathy. Again, there are no significant differences between the two groups.

Table I. Service Expectations, Service Perceptions and Overall Satisfaction

\begin{tabular}{|c|c|c|c|c|c|}
\hline & \multicolumn{2}{|c|}{ Public Sector } & \multicolumn{2}{|c|}{ Private Sector } & \multirow[b]{2}{*}{ Sig.(2-tailed) } \\
\hline & Mean & SD & Mean & SD & \\
\hline Overall service expectations & 4.81 & 1.36 & 4.92 & 1.19 & $\mathrm{t}(196)=.626$, n.s. \\
\hline Perceptions: tangibles & 4.34 & .91 & 4.64 & .97 & $t(194)=2.25, p<.05$ \\
\hline Perceptions: reliability & 4.38 & 1.52 & 4.26 & 1.35 & $\mathrm{t}(193)=-.592$, n.s. \\
\hline Perceptions: responsiveness & 4.31 & 1.43 & 4.50 & 1.33 & $\mathrm{t}(196)=.942, \mathrm{n} . \mathrm{s}$ \\
\hline Perceptions: assurance & 4.62 & 1.31 & 4.59 & 1.42 & $\mathrm{t}(196)=-.157$, n.s. \\
\hline Perceptions: empathy & 4.46 & 1.36 & 4.38 & 1.32 & $\mathrm{t}(193)=-.430$, n.s. \\
\hline Overall service satisfaction & 4.51 & 1.63 & 4.72 & 1.73 & $\mathrm{t}(197)=.871$, n.s. \\
\hline
\end{tabular}


Comparing the level of overall service expectations and the aggregated mean score of service perceptions within groups, the data suggest that there is a significant difference between service expectations and perceptions in the public sector $(\mathrm{t}(91)=2.277, \mathrm{p}<.05)$ and the private sector $(\mathrm{t}(91)=3.090, \mathrm{p}<.05)$, with expectations being significantly higher than perceptions.

To address research objective 3, multiple regression analyses were carried out independently for the public and private sector group in order to assess the relative impact of the five SERVQUAL dimensions on overall satisfaction with the services received. The results of this procedure can be found in Figure 1.

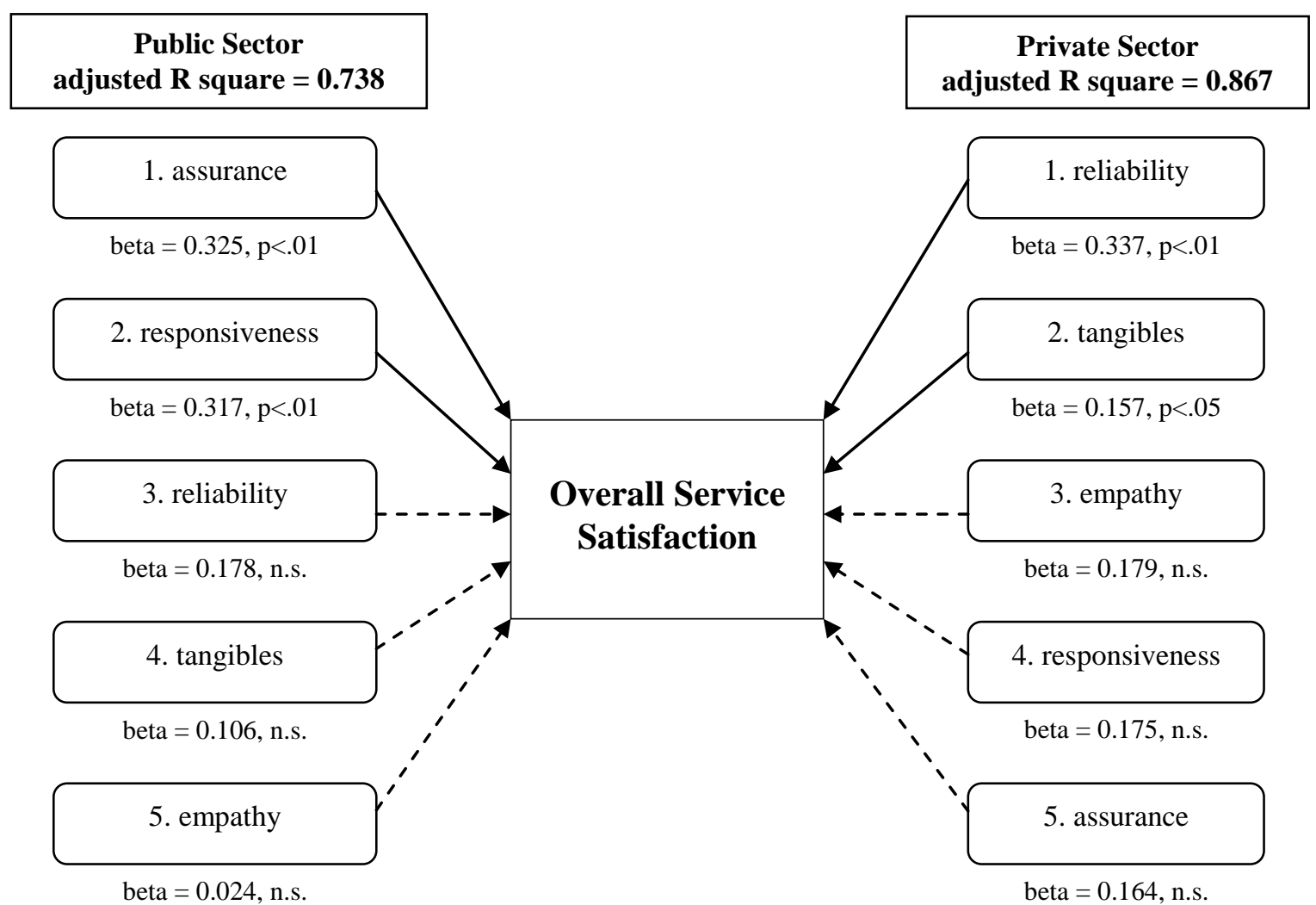

Figure 1. Drivers of Overall Service Satisfaction

As can be seen, the dimensions have a strong predictive power for overall satisfaction, explaining $74 \%$ of the variance in the public sector, and $87 \%$ in the private sector respectively. While this means that the SERVQUAL dimensions explain the majority of variance in overall satisfaction in both sectors, the results also suggest that there are considerable differences in relation to the dimensions that have a significant impact on overall satisfaction: In the public sector, assurance and responsiveness are the main predictors of recipients' satisfaction with the services received, whereas reliability and tangibles are the key drivers in the private sector.

\section{CONCLUSIONS AND IMPLICATIONS}

To start, it needs to be said that the sample size used in this study is relatively small. Thus, the results presented here need to be treated with caution. Nevertheless, this study makes several important contributions to the debate in the extant literature.

First, it provides an insight into how levels of service quality compare between the private and the public sector from the recipients' perspective. For example, the results suggest that levels of expectations towards and perceptions of private and public services are similar. This contradicts the traditional notion that the quality of public 
services is inferior to those of the private sector (Parker and Bradley, 2000). It is important to understand why this is the case. One explanation could be that, overall, public service provision has improved. The alternative explanation is that private sector services have been deteriorating. Obviously, the two are not mutually exclusive. But, regardless of the direction of this development, it is important from a marketing perspective to gain a better insight into if and how customers' perceptions of private sector services influence their expectations and perceptions as citizens towards public sector services, and vice versa. This will help to identify and implement appropriate marketing strategies to enhance service performance in individual sectors and industries by taking service quality in other sectors into account.

Second, the majority of studies in the field of public administration have concentrated on exploring the assimilation between the public and the private sector from a management perspective. While the debate has centred around the benefits of and problems with the introduction of private sector practices in the public sector, the focus on the very reason for this initiative has been lost at times: to provide the public with improved, tailored and responsive services (Micheli et al., 2005; Radnor and McGuire, 2004;Woodell, 2002). One of the main barriers to a service re-orientation of public sector organizations lies in the transition from being internally focused, with a focus on compliance to structures and rules, to being externally driven, with an emphasis on meeting recipients' changing needs (Maddock, 2002). On that basis, a more comprehensive research agenda including a stronger marketing perspective, which also looks at public service provision from the recipients' viewpoint as being also customers of private services, needs to be developed.

This links in with the third contribution of the paper: The data reveal that there are significant differences between service expectations and perceptions in both sectors. This result is not surprising for the private sector, where the overpromising of service processes and outcomes through marketing communications initiatives is commonplace. In the case of the public sector, it is possible that the rhetoric of politicians, influenced by differing stakeholder agendas, also misleads citizens as to what they can expect from public services. As documented in the literature, the creation of false expectations can lead to increased frustration and dissatisfaction with services in general (Chumpitaz et al., 2007; Heskett et al., 1994; Parasuraman et al., 1988). Potential consequences for private sector services include the loss of customers, revenue and ultimately profit. On this basis, there is great merit in investigating further how marketing strategies can be implemented to narrow the gap between customers' expectations and perceptions. In the public sector, this identified gap could act counterproductive to the modernisation efforts of public services. For example, Hirschman (1970) commented on citizens' options to voice their concerns or abandon political engagement all together, which would be detrimental to democratic values. Therefore, strategies for the public sector need to be identified in order to achieve a better match between service expectations and the actual delivery of services.

Finally, the paper also contributes to the extant body of literature concerned with the measurement of service quality and its antecedents in general. As mentioned above, the SERVQUAL tool has been widely debated, with some contradicting evidence concerning its statistical properties (Arambewela and Hall, 2006; Brysland and Currie, 2001; Cronin and Taylor, 1992; Parasuraman et al., 1988). In particular, its reliability and validity across different service contexts have been questioned. The preliminary analysis of the data presented here reveals that there is not an ideal fit between the model and the data. This is in the main due to the cross-loadings of some items which impacts on the discriminant validity of the five dimensions. However, the dimensions, although significantly different for each sector, explain a very high percentage of the variance in overall service satisfaction in the public and the private sector. Based on the assumption that the perceptions of these dimensions are antecedents of overall service quality, the results provide support for the construct validity of the measurement tool. Nevertheless, the underlying reasons for the differences in the predictive power of individual dimensions between the two sectors need further investigation. Finally, while the traditional SERVQUAL dimensions predict overall customer satisfaction well, they are not exhaustive and do not consider alternative modes of service delivery, such as online channels. Therefore, it needs to be considered how, for example, e-service dimensions (Herington and Weaven, 2009; Parasuraman et al., 2005) are best included to capture service performance judgements across sectors. 


\section{AUTHOR INFORMATION}

Barbara Caemmmerer is Professor of Marketing at ESSCA School of Management, LUNAM University, France. Beforehand she worked sevaral years as a Lecturer at the University of Strathclyde, UK. Her research focuses on services marketing and management and has been funded by a variety of private and public sector organisations. Email: barbara.caemmerer@essca.fr (Corresponding author)

Alistair Dewar, a graduate in Marketing from the University of Strathclyde, is currently in the Wholesale Banking Division for Lloyds TSB where he works in the field of marketing and key account strategy development.

\section{REFERENCES}

1. Arambewela, R. and Hall, J. (2006), "A comparative analysis of international education satisfaction using SERVQUAL", Journal of Services Research, Vol. 6, Special issue, pp. 141-164.

2. Black, S., Briggs, S. and Keogh, W. (2001), "Service quality performance measurement in public/private sectors", Managerial Auditing Journal, Vol. 16, No. 7, pp. 400-405.

3. Bolton, M. (2003), "Public sector performance measurement: delivering greater accountability", Work Study, Vol. 52, No. 1, pp. 20-25.

4. Bowman, D. and Narayandas, D. (2004), "Linking customer management effort to customer profitability in business markets", Journal of Marketing Research, Vol. 41, November, pp. 433-47.

5. Brysland, A. and Currie, A. (2001), "Service improvements in public services using SERVQUAL", Managing Service Quality, Vol. 11, No. 6, pp. 389-402.

6. Buttle, F. (1996), "SERVQUAL: Review, critique, research agenda", European Journal of Marketing, Vol. 30, No. 1, pp. 8-33.

7. Byrne, B. (2001), Structural Equation Modelling with AMOS, Lawrence Erlbaum, New Jersey.

8. Caemmerer, B. and Banerjee, M. (2009), "Understanding service relationship management in the private and public sector", Journal of Relationship Marketing, Vol. 8, No. 1, pp. 68-79.

9. Caruana, A. (2002), "Service loyalty - the effects of service quality and the mediating role of customer satisfaction", European Journal of Marketing, Vol. 36, No. 7, pp. 811-828.

10. Chiou, J-S., and Droge, C. (2006), "Service quality, trust, specific asset investment, and expertise: Direct and indirect effects in a satisfaction-loyalty framework", Journal of the Academy of Marketing Science, Vol. 34, No. 4, pp. 613-27.

11. Chumpitaz, R. and Paparoidamis, N. (2007), "Service quality, relationship satisfaction, trust, commitment and business-to-business loyalty", European Journal of Marketing, Vol. 41, No. 7/8, pp. 836-867.

12. Claver, E., Llopies, J., Gasco, J., Molina, H. and Conca, F. (1999), "Public administration: from bureaucratic culture to citizen-oriented culture", International Journal of Public Sector Management, Vol. 12, No. 5, pp. 455-464.

13. Coplin, W., Merget, A. and Bourdeaux, C. (2002), "The professional researcher as change agent in the government-performance movement", Public Administration Review, Vol. 62, No. 6, pp. 699-684.

14. Cronin, J. and Taylor, S. (1992), "Measuring service quality: a re-examination and extension", Journal of Marketing, Vol. 56, pp. 55-68.

15. Donnelly, M., Wisniewski, M., Dalrymple, J. and Curry, A. (1995), "Measuring service quality in local government: the SERVQUAL approach", International Journal of Public Sector Management, Vol. 8, No. 7, pp. 15-20.

16. Durvasula, S., Lysonski, S., and Mehta, S. (2005), "Service encounters: the missing link between service quality perceptions and satisfaction", Journal of Applied Business Research, Vol. 21, No. 3, pp. 15-26.

17. EPSI Rating (2009), "International benchmark trends for customer satisfaction and consumer sentiment monitoring, 1999-2009", data available at: http://www.epsi-rating.com/, accessed: 01/04/2013.

18. Galloway, L. (1998), "Quality perceptions of internal and external customers: a case study in educational administration", The TQM Magazine, Vol. 10, No. 1, pp. 20-26.

19. du Gay, P. and Salaman, G. (1992), "The cult(ure) of the customer", Journal of Management Studies, Vol. 29 , pp. 615-633.

20. Gianakis, G. (2002), "The promise of public sector performance measurement: anodyne or placebo?", Public Administration Quarterly, Vol. 26, pp. 35-65. 
21. Gronroos, C. (1982), "A service quality model and its management implications”, Research Report. EIASM Workshop on Research into the Management of Services, London.

22. Gronroos, C. (1990), "Relationship approach to marketing in service contexts: the marketing and organizational behaviour interface", Journal of Business Research, Vol. 20, No. 1, 3-12.

23. Hair, J., Anderson, R., Tathman, R. and Black, W. (1998), Multivariate Data Analysis, Prentice Hall, New Jersey.

24. Herington, C. and Weaven, S. (2009), "E-retailing by banks: e-service quality and its importance to customer satisfaction", European Journal of Marketing, Vol. 43, No. 9/10, pp. 1220-1231.

25. Heskett, J., Jones, T., Loveman, G., Sasser, W. and Schlesinger, L. (1994), "Putting the service-profit chain to work", Harvard Business Review, March-April, pp. 164-174.

26. Hirschman, A. (1970), Exit, voice and loyalty: response to decline in firms, organizations and states, Harvard University Press, MA.

27. Hoffman, K. and Bateson, J. (1997), Essentials of Services Marketing, Dryden Press, Fort Worth.

28. ICS (2009), "UKCSI - Service sector results", report available at: http://www.instituteofcustomerservice.com/, accessed 25/08/2010.

29. Jamal, A. and Anastasiadou, K. (2009), "Investigating the effects of service quality dimensions and expertise on loyalty", European Journal of Marketing, Vol. 43, No. 3/4, pp. 398-420.

30. Kondylis, E. (1989), "Considerations on the public sector organizations performance: a systems approach", Journal of Applied Business Research, Vol. 5, No. 4, pp. 15-19.

31. Koutroumanis, D., Watson, M. and Dastoor, B. (2012), "Developing organizational culture in independently owned restaurants: links to service quality and customers' intentions to return", Journal of Applied Business Research, Vol. 28, No. 1, pp. 15-25.

32. Maddock, S. (2002), "Making modernisation work - new narratives, change strategies and people management in the public sector", International Journal of Public Sector Management, Vol. 15, No. 1, pp. 13-43.

33. Marini, F. (1993). Can't get no satisfaction: Customers, citizens, service, and satisfaction. Public Administration Review, Vol. 53, 170-173.

34. McAdam, R., Reid, R. and Saulters, R. (2002), "Sustaining quality in the UK public sector", International Journal of Quality and Reliability Management, Vol. 19, No. 5, pp 581-595.

35. Micheli, P., Mason, S., Kennerley, M. and Wilcox, M. (2005), "Public sector performance: efficiency or quality?", Measuring Business Excellence, Vol. 9, No. 2, pp. 68-74.

36. Murphy, K. and Davidshofer, C. (1998), Psychological Testing - Principles and Applications, Prentice Hall, New Jersey.

37. Parasuraman, A., Zeithaml, V., and Berry, L. (1985), “A conceptual model of service quality and its implications for future research", Journal of Marketing, Vol. 48, pp. 41-51.

38. Parasuraman, A., Berry, L. And Zeithaml, V. (1988), "SERVQUAL: a multiple-item scale for measuring consumer perceptions of service quality", Journal of Retailing, Vol. 64, pp. 12-40.

39. Parasuraman, A., Zeithaml, V. and Malhotra, A. (2005), "E-S-Qual: A multiple-item scale for assessing electronic service quality“, Journal of Service Research, Vol. 7, No. 3, pp. 213-234.

40. Parker, R. and Bradley, L. (2000), "Organizational culture in the public sector: evidence from six organizations", The International Journal of Public Sector Management, Vol. 13, No. 2, 125-137.

41. Piercy, N. and Rich, N. (2008). "High quality and low cost: the lean service centre", European Journal of Marketing, Vol. 43, No. 11/12, pp. 1477-1497.

42. Radnor, Z. and McGuire, M. (2004), "Performance management in the public sector: fact or fiction?", International Journal of Productivity and Performance Management, Vol. 53, No. 3, pp. 245-260.

43. Rhee, Se-K. and Rha, J-Y. (2009), "Public service quality and customer satisfaction: exploring the attributes of service quality in the public sector", Service Industries Journal, Vol. 29, No. 11, pp. 14911512.

44. Rosen, D. And Surprenant, C. (1998), "Evaluating relationships: are satisfaction and quality enough?", International Journal of Service Industry Management, Vol. 9, No. 2, pp. 103-125.

45. Turner, K., Bienstock, C. and Reed, R. (2010), “An application of the conceptual model of service quality to independent auditing services", Journal of Applied Business Research, Vol. 26, No. 4, pp. 1-7.

46. Voss, C., Tsikriktsis, N. and Frohlich, M. (2002), "Case research in operations management", International Journal of Operations and Production Management, Vol. 22, No. 2, pp. 195-219. 
47. Woodell, V. (2002), "Consulting in the public sector: challenges and opportunities", Organization Development Journal, Vol. 20, No. 2, pp. 91-96.

48. Zeithaml, V. and Bitner, M. (2000), Services Marketing, McGraw-Hill, New York.

49. Zeithaml, V., Berry, L. and Parasuraman, A. (1996), "The behavioural consequences of service quality", Journal of Marketing, Vol. 60, No. 2, pp. 31-47.

50. Zeithaml, V., Bitner, M. and Gremler, D. (2006), Services Marketing - Integrating Customer Focus across the Firm, McGraw-Hill, New York. 